\title{
Electron microscopy of Precambrian Vallenia from Greenland
}

\author{
HANS JØRGEN HANSEN
}

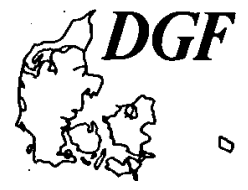

Hansen, H. J.: Electron microscopy of Precambrian Vallenia from Greenland. Bull. geol. Soc. Denmark, vol. 27, Special Issue, pp. 55-61, Copenhagen, July 30th 1978. https://doi.org/10.37570/bgsd-1978-SI-07

\begin{abstract}
Previously described structures within the Precambrian supposed plant fossil Vallenia erlingi Pedersen, 1967 from southwest Greenland were re-studied using STEM, high voltage TEM and x-ray microanalysis. It is concluded that the inner cell structure most likely is caused by twinning in the mineral phlogopite and is unrelated to the original cell structure.
\end{abstract}

H. J. Hansen, Geologisk Centralinstitut, University of Copenhagen, Øster Voldgade 10, DK-1350 Copenhagen K, Denmark. May 24th, 1978.

Bondesen, Pedersen \& Jørgensen (1967) and Pedersen (1967) described Precambrian plant fossils from a dolomitic horizon in southwest Greenland. Radiometric dating indicated an age for the fossils of not younger than $1800 \mathrm{MY}$.

The geologic setting, the supposed plant remains as well as their composition with respect to carbon isotopes and organic compounds were described in the above mentioned paper.

Later Lam and Pedersen (1968) described the different carbon compounds extracted from the rock containing Vallenia thereby further supporting the hypothesis that the observed structures are of organic origin.

Later collection of fossils from the relevant horizon has given addtional information regarding composition of the fossils as well asgood examples for the study of the supposed relict inner cell structures illustrated by Pedersen in Bondesen et al. (op.cit.).

The purpose of the present paper is to present the results of a renewed study of the supposed inner cell structure using methods not applied by Bondesen et al. (1967).

\section{Methods}

Rock slices were dissolved in $5 \% \mathrm{HCl}$ to free the specimens of their matrix. The isolated specimens were studied by scanning electron microscopy (SEM).

Conventional petrographic thin sections were studied under the light microscope using polarized light.

Polished pieces of the rock containing the fossils were studied in the SEM using $x$-ray analytical equipment. Other specimens were thinned by ionmilling (following methods described in Towe and Thompson (1972) and in Conger and Green (1976)) in order to obtain ultra-thin preparations that would allow high voltage transmission electron microscopy (TEM) as well as scanning transmission electron microscopy (STEM) at $60 \mathrm{KV}$.

The study was carried out in the Laboratory of Electron Microscopy, University of Copenhagen.

The $200 \mathrm{KV}$ TEM placed in the Laboratory of Applied Physics I, Technical University of Denmark, was made available to the author. Dr. I. Hansson is thanked for his kind help and advice.

The samples were kindly put at the author's disposal by Dr. A.K. Higgins and Dr. J.S. Peel, Geological Survey of Greenland. Prof. Dr. H. Micheelsen, Mineralogical Institute, kindly made the optical measurements. He and Dr. K. Raunsgaard Pedersen, University of Ȧrhus, read the manuscript and suggested improvements. Dr. J.S. Peel kindly improved the language of the manuscript. This paper is published with the approval of the Director, Geological Survey of Greenland. The specimens are registered under GGU no. 71380-DH-Q-U-V. 

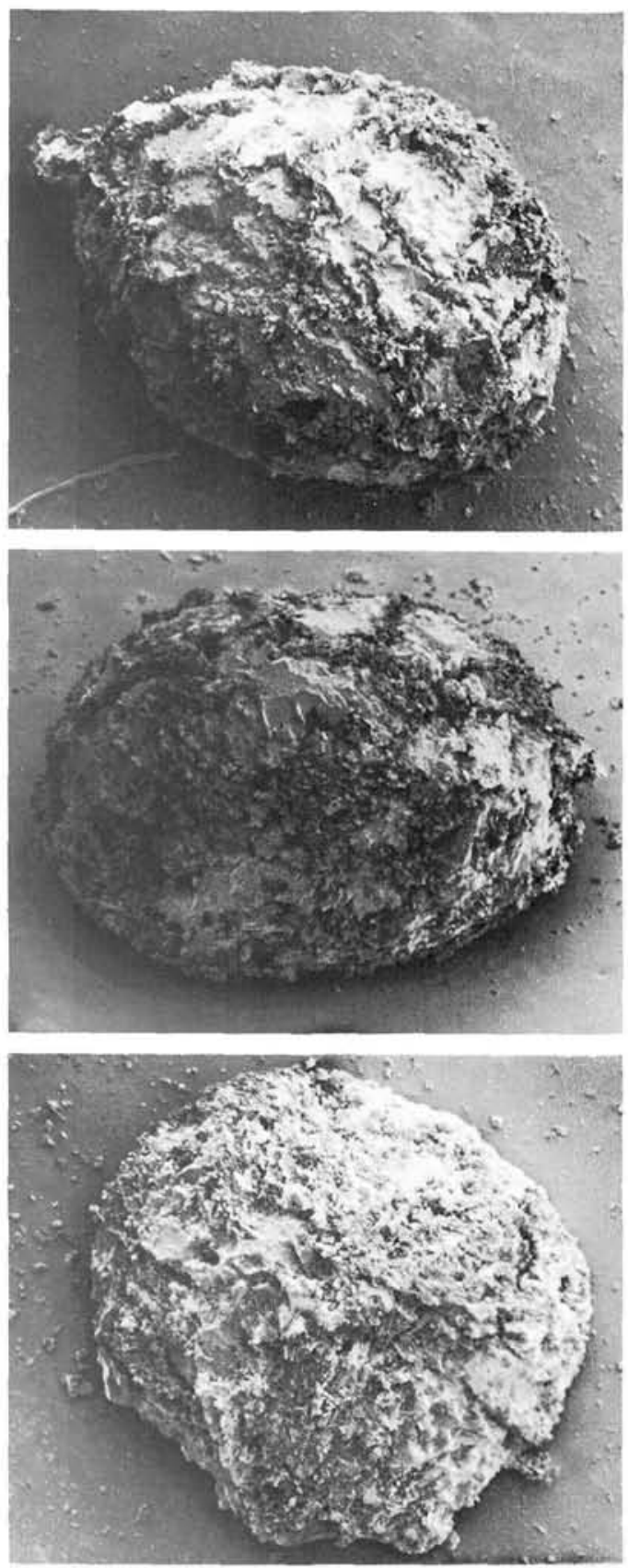

Fig. 1-3. Vallenia erlingi Pedersen, 1967. Isolated specimens demonstrating general shape. Figs, 2-3 are sectioned individuals. Fig. 1: $70 x$. Fig. 2: $62 x$. Fig. 3: $70 x$. SEM.

\section{Remarks on the structure of Vallenia}

Individuals of Vallenia are spherical, or in some instances elongate (figs. 1-3). The usual pattern

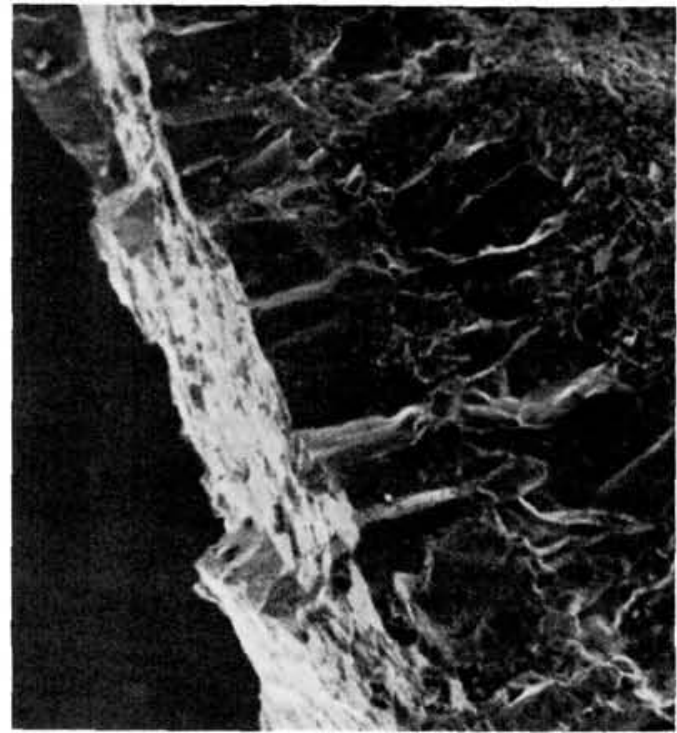

Fig. 4. Detail of sectioned, isolated specimen showing double outer layer of quartz with radiating growth followed by core part (upper right) of fine grained non-carbonate material. $765 x$. SEM.

seen in sections of Vallenia erlingi is one of an outer dark narrow ring followed by a zone or circular band of quartz which in the sections appears bright. X-ray analysis showed the composition of the material in the dark narrow outer ring to be a mixture of quartz and a mineral containing $\mathrm{K}, \mathrm{Mg}$, $\mathrm{Al}, \mathrm{Si}$ (most likely phlogopite) and in some cases Mg-rich calcite or dolomite (fig. 4).

The next zone following the quartz-rich one is generally of a dark colour under the light microscope. This zone may extend through the whole of the body or it may change into an inner core with a different texture. In some cases an additional core is found.

The two-layered wall described earlier (Pedersen in Bondesen et al. 1967) would appear to have some relation to diagenetic processes. In some instances two concentric thin layers are seen, but more commonly only one layer occurs. Pedersen in Bondesen et al. (op.cit.) found connecting thin threads between the two concentric layers in some specimens.

It appears relevant to vizualize a diagenetic process involving shrinkage as a main reason for the two layers. In such a model the described threads become intelligible in terms of extensions of the 


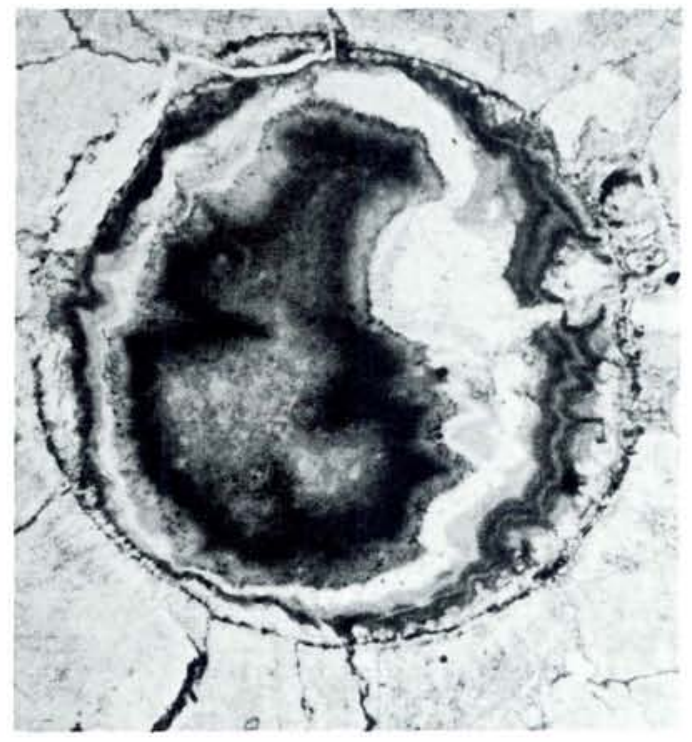

Fig. 5. Light micrograph of sectioned specimen showing zonation as well as supposed shrinkage phenomena. $85 x$.

outer wall together with shrinkage of the core material (the cell content) (fig. 5). The shrinkage not only causes the development of a space between the cell content and the inside of the outer layer, but may also have lead to the formation of a central void or cavity. The central cavity has in some instances been filled by layered material which, in its occurrence, is reminiscent of the structure seen macroscopically in agate. In other examples an apparent nucleation and subsequent radiating growth of phlogopite in the cavity is observed.

There can be very little doubt that the core-part appearing dark under the light microscope owes its colour to a concentration of carbon present in the primary cell.

In general the material making up the dark part has the composition of phlogopite. The same material may fill the central cavity. Some examples are seen, however, in which part of the central core is composed of quartz.

\section{The supposed inner relict cell structures}

Pedersen in Bondesen et al. (op.cit.) described structures from the core material which under the

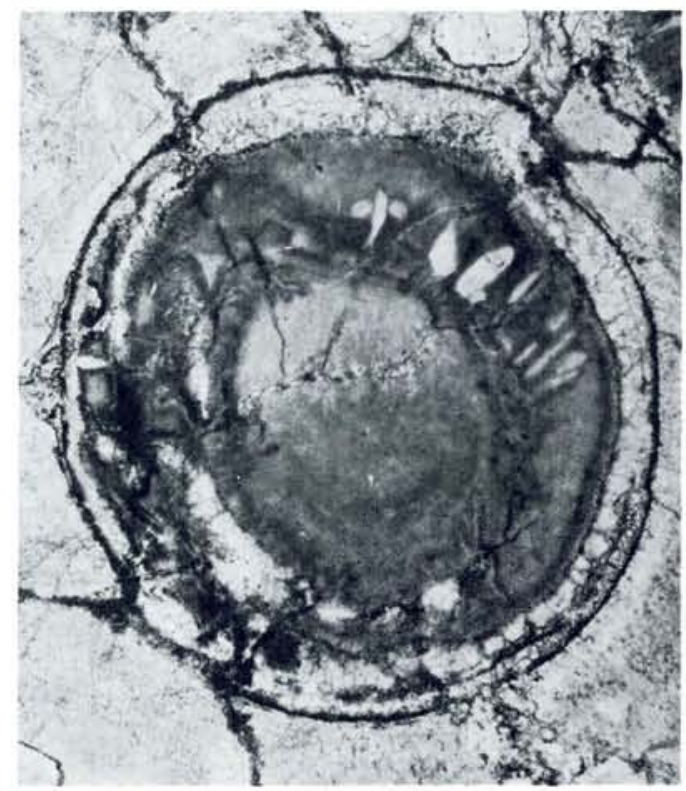

Fig. 6. Slightly deformed specimen showing outer quartz zone as well as dark core part. $85 x$. LM.

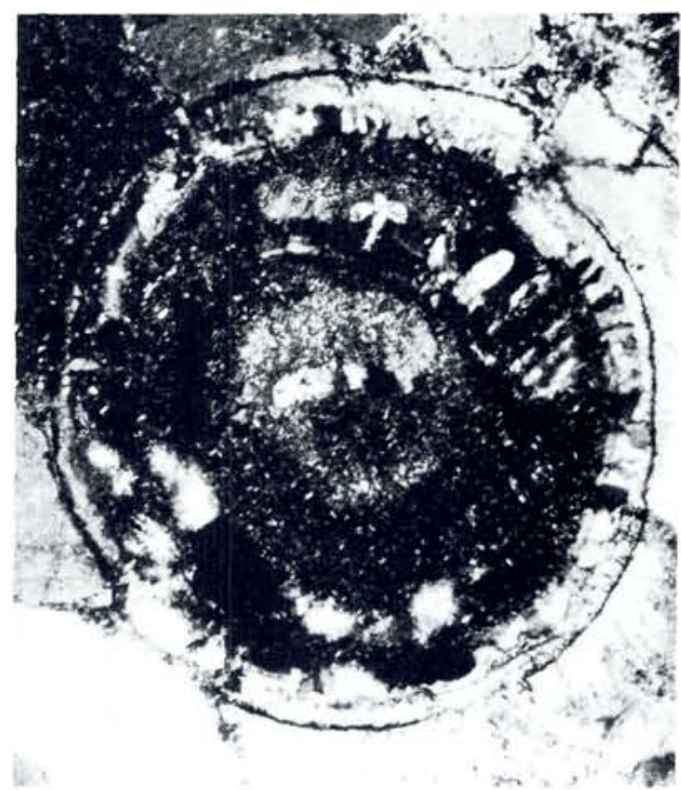

Fig. 7. Same specimen as in Fig. 6. Crossed nicols. 85 x. LM.

light microscope had a periodicity of $1 \mu \mathrm{m}$. These structures were related to primary organic structures in the fossils.

Uncovered petrographic thin sections of $\mathrm{Val}$ - 


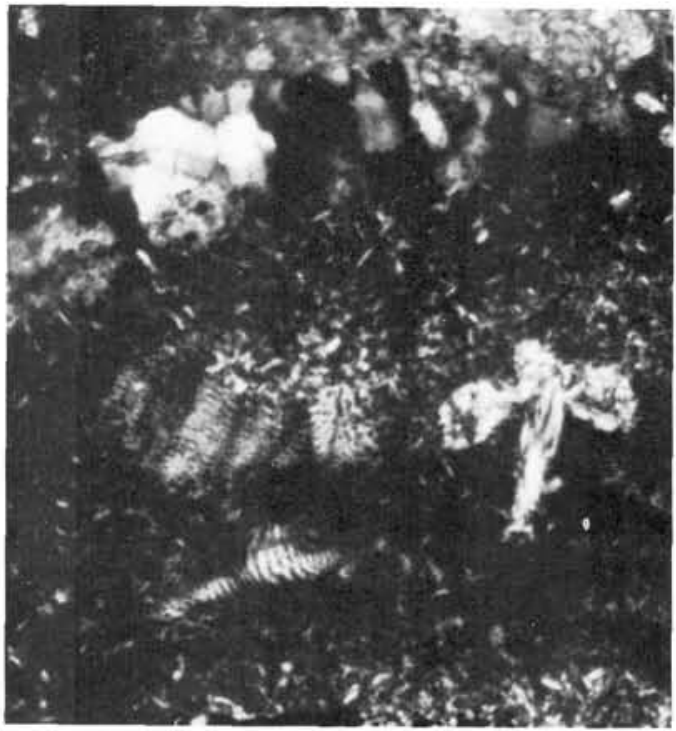

Fig. 8. Detail of fig. 7 showing subdivided rod-like structures in the core material. Crossed nicols. $300 x, L M$.

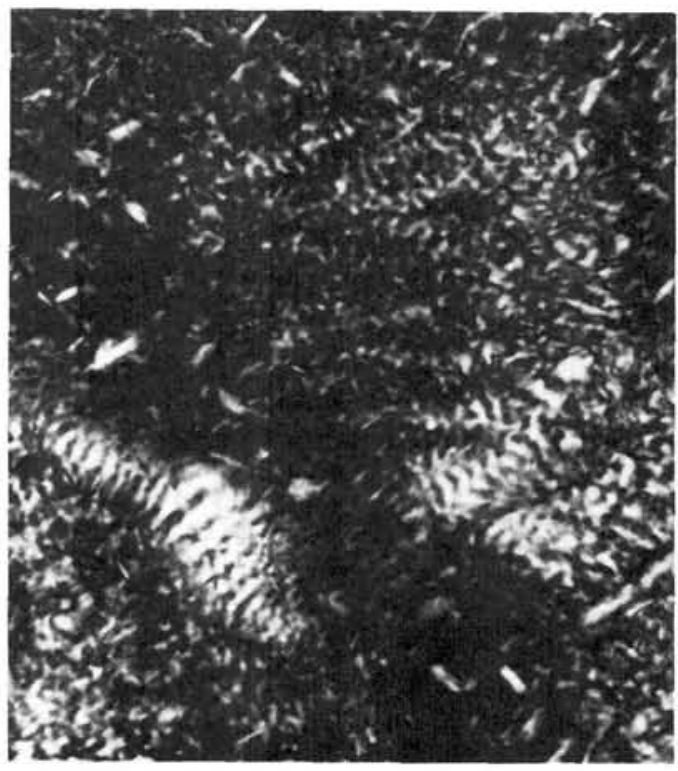

Fig. 9. Detail of fig. 8 showing almost radiating or subparallel, rod-like, subdivided core material. Specimen oriented $45^{\circ}$ relative to the situation in fig. 8. Crossed nicols. 830x. LM.

lenia from one of the localities (no. 1) of Bondesen et al. (1067) showing the $1 \mu \mathrm{m}$ periodicity of the core material (figs. 6-9) were treated with $5 \%$ $\mathrm{HCl}$. This caused the matrix rock to dissolve while

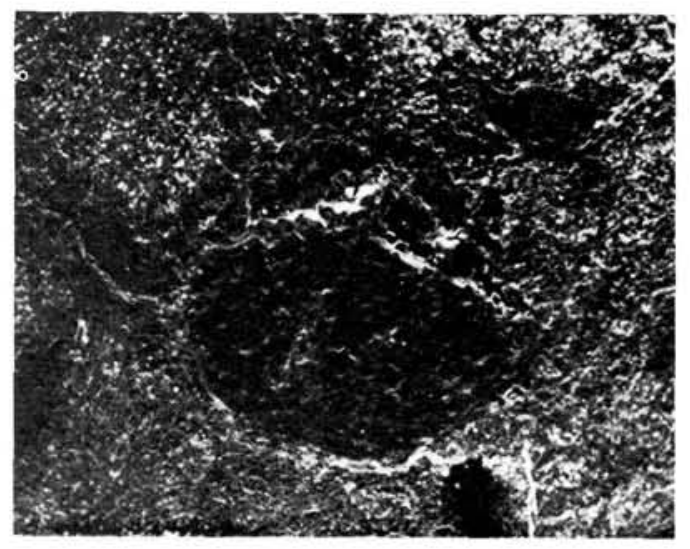

Fig. 10. Polished section of Vallenia 95 x. SEM.

the core material was left unaffected. Treatment of the isolated fossils with $0.5 \% \mathrm{HF}$, however, caused the structure to collapse completely, and a study of the supposed relict structures by embedding the acid residue and cutting ultrasections was not possible.

$\mathrm{X}$-ray distributional pictures of $\mathrm{Ca}$ and $\mathrm{Si}$ (figs. 11-12) showed that the inner part of the globular structures are made of material other than Ca-Mg carbonate. In some examples carbonate grains from the surrounding matrix were seen to penetrate into the globules, but this seems to be the exception rather than the rule.

In order to investigate the mineralogy of the material showing the supposed relict cell structures material from the core of two specimens from an un-covered thin section was extracted using a pointed scalpel.

The material was mounted with silicone grease on the tip of a glass needle and run in an $\mathrm{x}$-ray diffraction camera (Gandolfi rig) for 24 hours. The material was irradiated with $\mathrm{Cu}_{\mathrm{K} \alpha}$ radiation. The resultant diffraction pattern showed the mineral to be a $10 \AA$ mica.

X-ray microanalysis performed on ion-thinned specimens using thinned muscovite as standard showed a composition of the material which would agree well with the composition of the mineral phlogopite with $\mathrm{Si}, \mathrm{Al}, \mathrm{Mg}$ and $\mathrm{K}$ as the only major components above $\mathrm{Z}=11$. Fe is very low, indicating the mineral to be a $\mathrm{Mg}$-rich phlogopite.

Ion-thinned specimens studied by $200 \mathrm{KV}$ TEM showed the $1 \mu \mathrm{m}$ periodicity in the mineral as seen 


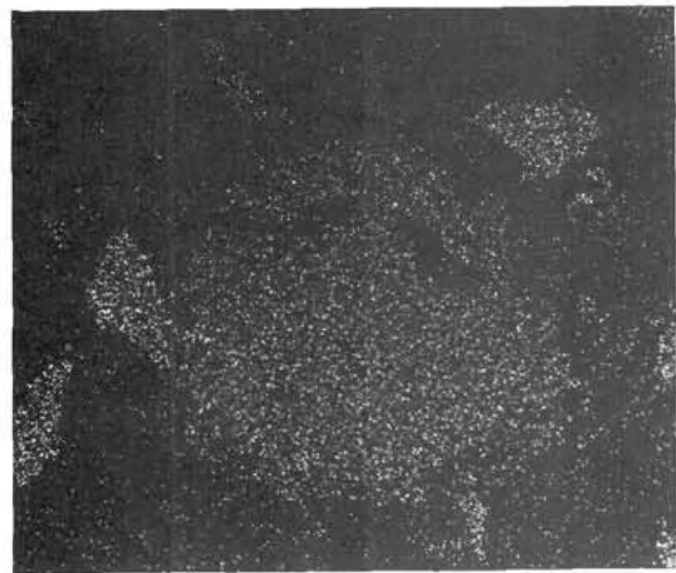

Fig. 11. Same specimen as fig. 10 showing distribution of characteristic $\mathrm{K}$-radiation of $\mathrm{Si}$.

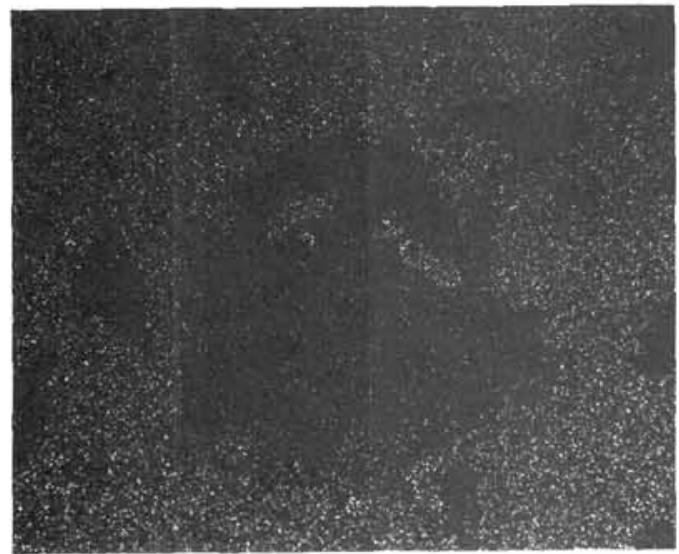

Fig. 12. Same specimen as in fig. 10 showing distribution of characteristic $\mathrm{K}$-radiation of $\mathrm{Ca}$. Note the strong negative correlation between Si and Ca.

under the light microscope (fig. 13). This was caused not by different elemental composition causing different electron absorption, but by diffraction contrast. X-ray microanalysis in the STEM of consecutive bands demonstrated no traceable chemical difference.

SEM pictures of crudely polished specimens showed a polishing relief with a $1 \mu \mathrm{m}$ periodicity (fig. 14).

Pedersen observed these structures using ordinary and not polarized light. Whether the structures observed by him was caused by different light refringence or by a concentration of carbon is not evident, but in view of the width of the dark

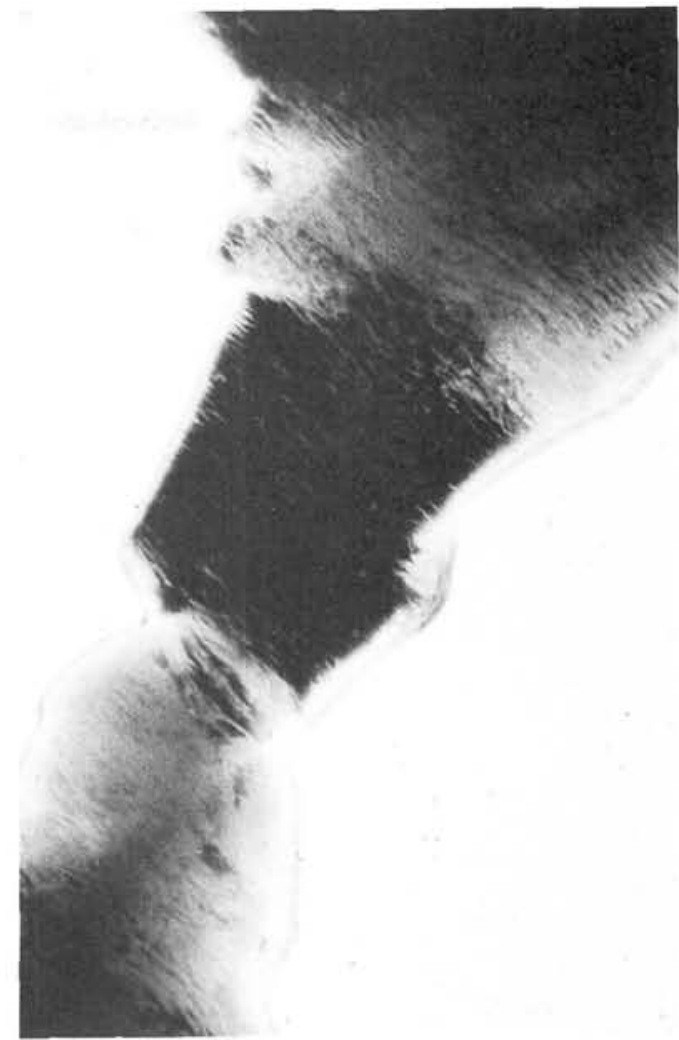

Fig. 13. Detail of thin foil specimen of core material of Vallenia. $35.000 x . T E M$.

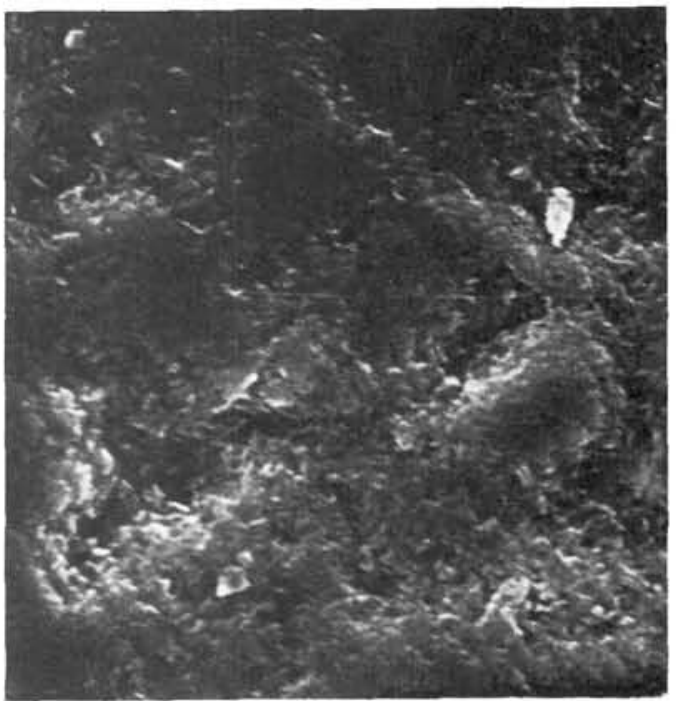

Fig. 14. Detail of crudely polished core material of Vallenia with a polishing relief with a periodicity of about I $\mu \mathrm{m} .2200 x$. SEM. 


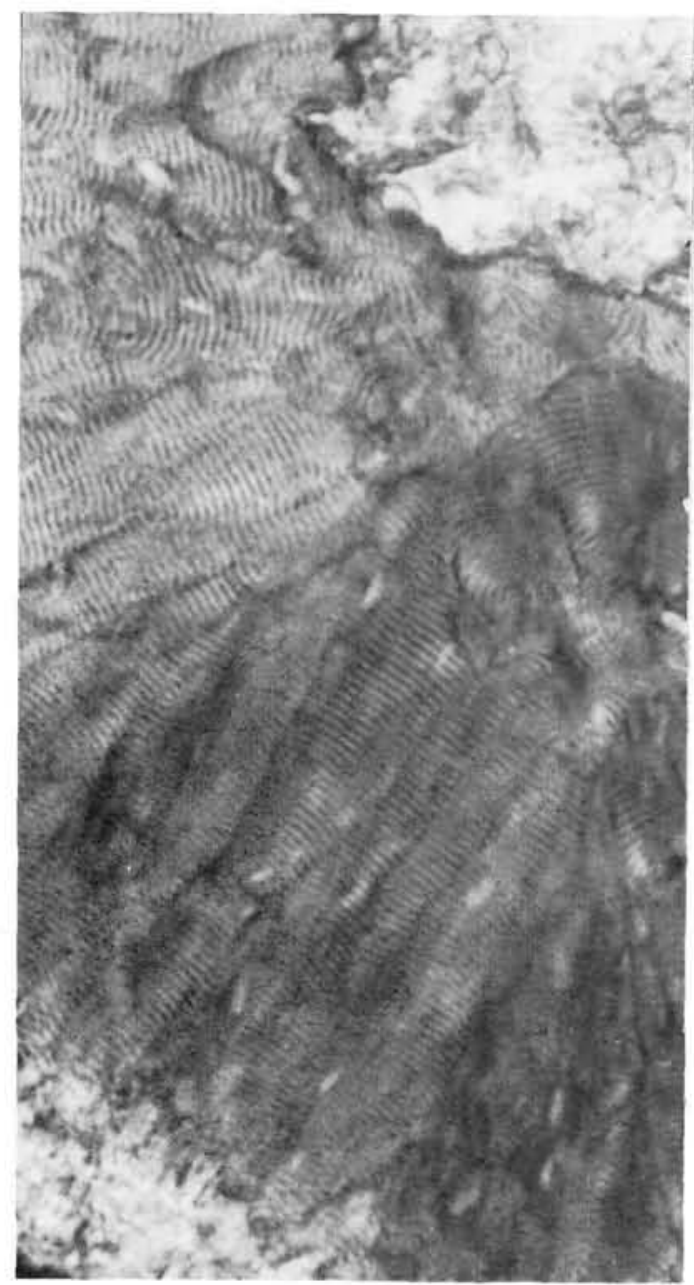

Fig. 15. Detail of core material of Vallenia. Polarized light. One nicol. Note the poor definition of the periodicity in the east-west direction, i.e. $\neq$ polarizer. $500 \times$. LM.

zones it would appear to be caused by refraction rather than some pigment (?carbon).

When studied under the light microscope using polarized light the banding disappears when the bands are perpendicular to the polarizer, while the bands are most pronounced when oriented parallel to the polarizer (figs. 15-18). Accordingly the banding cannot be caused by carbon pigmentation. Perpendicular to the bands the mineral shows radiating bundles with parallel extinction.

Various optical measurements kindly made by Dr. H. Micheelsen demonstrate that the $\alpha$ direction is perpendicular to the banding and that alternating bands have different n $\alpha$ ' values pointing to a repeated twinning with composition plane $\perp$

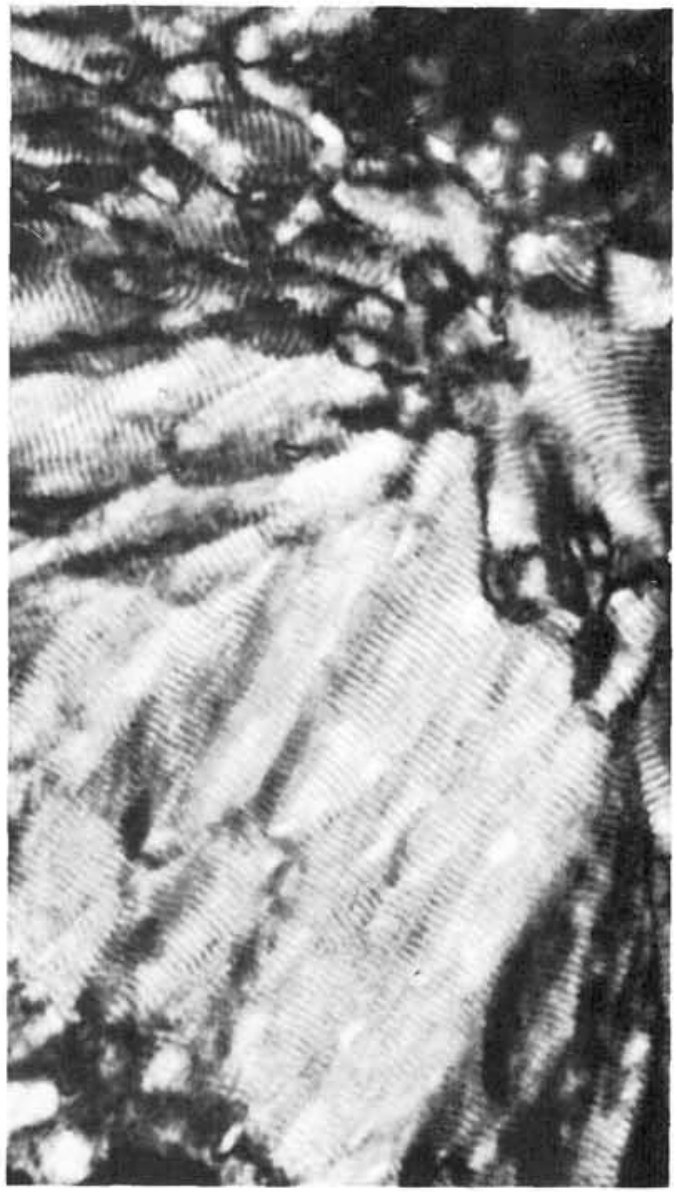

Fig. 16. Same detail as fig. 15. Crossed nicols.

[100] with a (0kl) face as twin plane. The details will be published elsewhere by Dr. H. Micheelsen.

The growth of the phlogopite seems to have started with scattered nucleation centres, leading in the earlier stages to the formation of a concentric banded or "layered" structure. These centres, with growth, and filling up of the available space, meet neighbouring individuals and are therefore forced to extend in one direction, developing into rod-like banded structures.

According to Deer, Howie \& Zussman (1962) the mineral phlogopite is characteristically found in metamorphosed limestones.

It therefore seems likely that the structures observed by Pedersen in Bondesen et al. (1967) do 


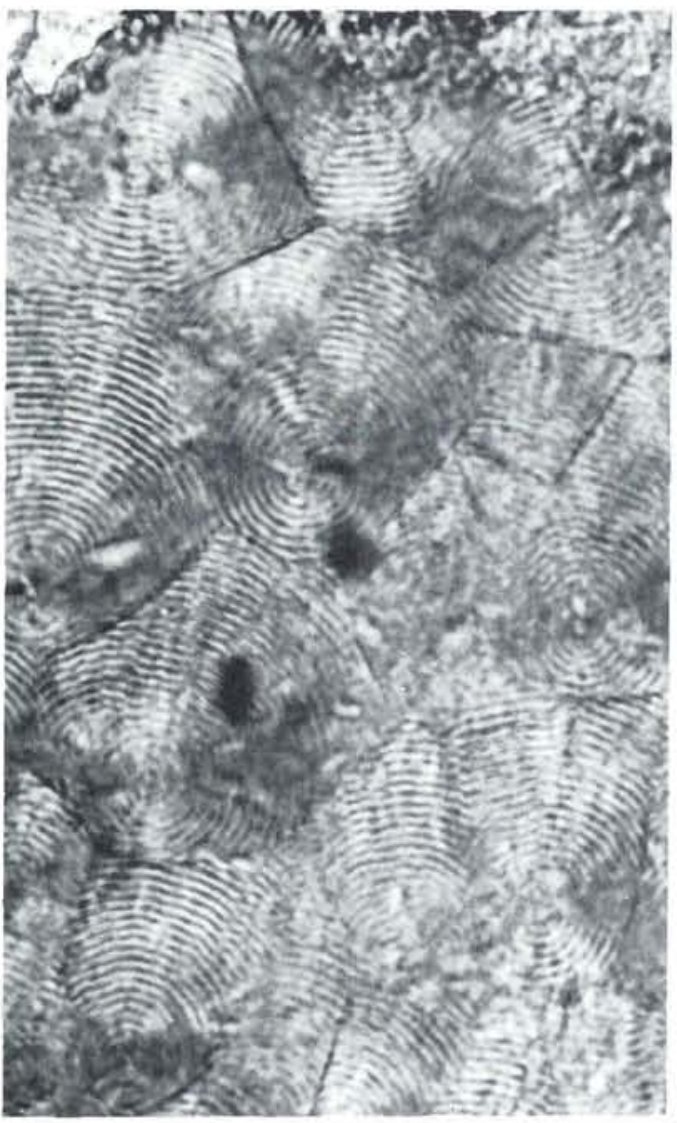

Fig. 17. Detail of specimen shown in fig. 15 but another area. Note poor definition of periodicity where twin boundaries are parallel with polarizer direction (north-south). $500 x$. One nicol. $L M$.

not represent inner cellular structures, but are caused by twinning in the mineral phlogopite. This is in agreement with the different reaction to polishing observed (fig. 14).

At the same time it must be emphasized that Pedersen's material originated from an area where the dolomitic limestone has suffered a lower degree of metamorphism than have the more northern exposures from where the main part of the additional material studied by the present author originates. This may well explain why Pedersen only met the structure in a few specimens.

\section{Dansk sammendrag}

Tidligere beskrevne indre strukturer fra det Prakambriske formodede plante fossil Vallenia erlingi Pedersen, 1967 fra SydvestGrønland er blevet gen-studeret ved hjælp af scanning- og højvoltstransmissions elektronmik roskopi og rentgenmikroanalyse.

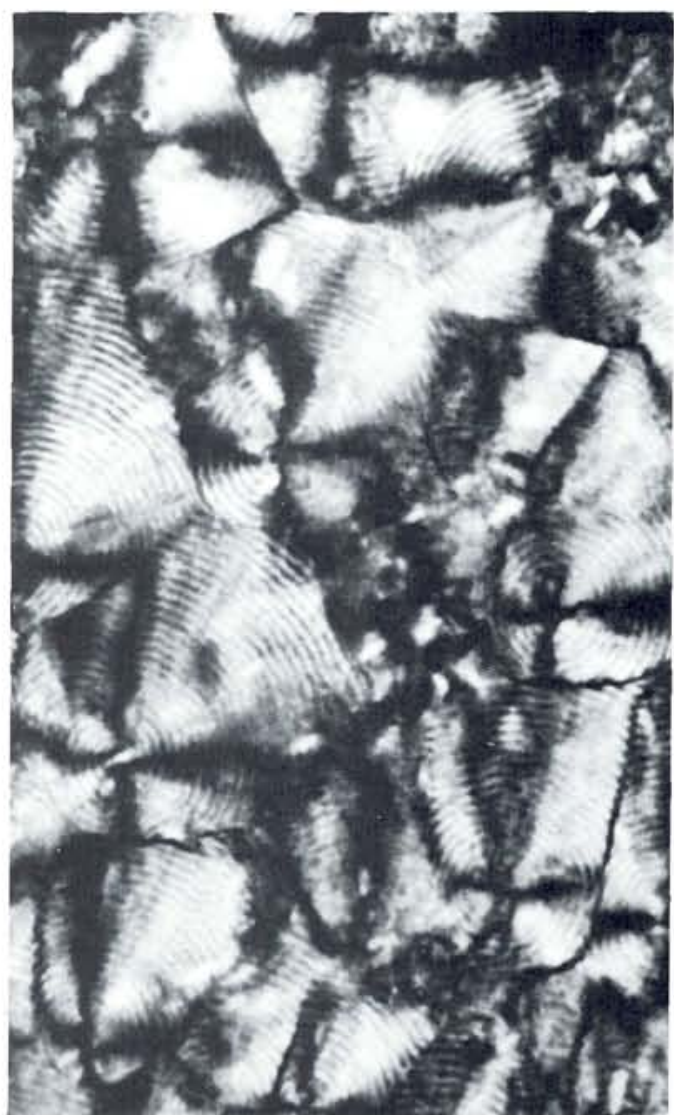

Fig. 18. Same detail as fig. 17. Crossed nicols.

Det konkluderes, at den indre cellestruktur sandsynligvis skyldes tvillingdannelse $\mathrm{i}$ mineralet phlogopit og ikke har nogen tilknytning til den oprindelige cellestruktur.

\section{References}

Bondesen, E., Pedersen, K.R. \& Jørgensen, O. 1967: Precambrian organisms and the isotopic composition of organic remains in the Ketilidian of south-west Greenland. Meddr Grenland, 164: 1-41

Conger, S.D. \& Green, H.W. 1976: Preparation of thin-foil specimens for transmission electron microscopy of microorganism tests. J. Paleont., 50: 795-798.

Deer, W.A., Howie, R.A. \& Zussman, J. 1962: Rock-forming minerals, vol. 3: Sheet silicates., 1-270. Longmans, Green \& Co., London.

Lam, J. \& Pedersen, K.R. 1968: Precambrian organic compounds from the Ketilidian of south-west Greenland. Part III. Meddr Grønland, 185, 6, 1-15.

Pedersen, K.R. 1967: Nogle prækambriske fossiler fra Vestgrønland. Meddr Dansk geol. Foren., 17: 195-196. (in Danish).

Towe, K.M. \& Thompson, G.R. 1972: The structure of some bivalve shell carbonates prepared by ion-beam thinning. Calc. Tiss. Res., 10: 38-48. 